\title{
DESIGING A SOFTWARE TO CALCULATE THE FIELD CAPACITY FOR FULL MECHANIZED AGRICULTURE PRACTICES IN LIGHT SOILS
}

\author{
Khater, M. M. I.*
}

\begin{abstract}
The selectivity of agricultural mechanization system in the new reclaimed areas must be based on anticipated performance. The most pertinent variable is the size or the capacity of the machine. A computer program was built and developed in Visual Basic programming language, to predicted implement field capacity. The data gathered during seedbed operations, planting and harvesting were used to provide time sequenced studies for equipment and operator productivity. Using data gathered in five new reclaimed areas were used to compare results from some field crops. Fields are relatively flat with straight-rows. The obtained results showed that the calculated values of theoretical and effective field capacities by the developed computer program were identified to that obtained in the field experiments. This means that the developed rogram is able to calculate the required parameters correctly.
\end{abstract}

Keywords: Visual Basic programming language, reclaimed areas, field efficiency, field capacity

\section{INTRODUCTION}

$\mathrm{M}$ achine capacity is a very important value for machinery management decisions. Machinery performance studies often used time techniques (Renoll 1981) with stop watches and recorded observations on a clip board. Today, low-cost computers, realtime controllers have combined to provide the necessary technology to make crop management and improved productivity and profitability. The selectivity of agricultural mechanization system in the new reclaimed areas must be based on anticipated performance which, the most pertinent variable is the size or the capacity of the machine. Forward speed and power were affecting on both field capacity and effectiveness of operation (Donnell 2001).

\section{*Desert Research Center, Cairo, Egypt}


From other point (Witney 1988) indicated that implement might be selected depending on width for getting sufficient capacity then, work to be done within allotted time, therefore, selection of width can be estimated as the follows:

$$
\mathrm{W}=(\mathrm{EFC} . \mathrm{CF}) / \mathrm{SE}
$$

Where:

$\mathrm{W}=$ optimum width, $\mathrm{m}$.

$\mathrm{EFC}=$ effective field capacity, ha/h.

$\mathrm{CF}=$ correction factor.

$\mathrm{S}=$ forward speed, $\mathrm{km} / \mathrm{h}$.

$\mathrm{E}=$ field efficiency

Any agricultural machinery system depend mainly on the performance which is an important measure to adapt the operation time with its sensitivity to quality describing a machine ability to operate without wasted time. Field capacity of an agricultural machine is the rate at which farm operations are accomplished (Robert $\boldsymbol{e t}$. al, 2000). The theoretical field capacity of an implement is the rate of field coverage that would be obtained when the machine is performing its function using hundred percent of the time at the rated forward speed and always covering hundred percent of the rated width (Kepner et. al, 1978). From other point, (Morad and El-Shazly 1994)) mentioned an equation of theoretical field capacity as follows:

$$
\mathbf{T F C}=(\mathbf{S . W}) / \mathrm{C}
$$

Where

$\mathrm{TFC}=$ theoretical field capacity, ha/h.

$\mathrm{S}=$ speed, $\mathrm{km} / \mathrm{h}$.

$\mathrm{W}=$ implement width, $\mathrm{m}$.

$\mathrm{C}=$ constant $=10$.

The effective field capacity is the actual rate of performance of land or crop processed in a given time and it can be expressed in area / time or material / time. It was found that the effective field capacity was affected by the implement size, (Ahmed and Haffar 1993). reported that disc harrow showed higher effective field capacity in light soils as compared 
with heavy soils. Farmer can increase field capacity by increasing the operating speed or implement width, it would appear that doubling the size or speed would double capacity. As reported in (ASAE 2003). Field efficiency is the ratio between the productivity of a machine under field conditions and the theoretical maximum productivity. Field efficiency accounts for failure to utilize the theoretical operating width of the machine; time lost because of operator capability, habits, operating policy and field characteristics. Travel to and from a field, major repairs, preventive maintenance, and daily service activities are not included in field time or field efficiency. Field efficiency is not a constant for a particular machine, but varies with the size and shape of the field, pattern of field operation, crop yield, moisture, and crop conditions. The following activities account for the majority of time lost in the field: 1turning and idle travel; 2- materials handling; 3- cleaning clogged equipment; 4- machine adjustment; 5- lubrication and refueling (besides daily service); 6- waiting for other machines. The effective capacity can be calculated on area base or material base as follow:

\section{$\mathrm{Ca}=($ S.W.Ef $) / 10$}

Where

$\mathrm{Ca}=$ area capacity, ha/h.

$\mathrm{S}=$ field speed, $\mathrm{km} / \mathrm{h}$.

$\mathrm{W}=$ implement working width, $\mathrm{m}$.

$\mathrm{Ef}=$ field efficiency.

(Randal et al. 2001) reported that field efficiency decreased with increasing planter width. Field size had little impact on field efficiency. Field efficiency includes the effect of the time lost in the field and failure to utilize the full width of the machine (Bower 1985). It is not constant for a particular machine, but varies with the size and shape of the field, pattern of the field operation, crop yield, moisture and crop condition. $\mathrm{He}$ also added that, the lost time is the most important factor that affects the field capacity and efficiency of a machine. It may be lost as a result of adjusting or lubricating the machine, break downs, clogging turning at the ends, adding seeds fertilizer or operator personal time. The factors affecting field efficiency, as theoretical capacity of the machine, machine 
maneuverability, field shape, field patterns, field size, yield (if harvesting operation), soil and crop condition and system limitation. Implement type and soil physical condition are important factors affecting the field capacity and efficiency of tillage implement, when soil condition are poor for machine operations forward speed will usually be reduced. (Belel and Dahab 1997) found that chisel plow recorded lower values of power requirement, theoretical field capacity and effective field capacity in loose clay soil as compared to disk plow, and moldboard plow.

The overall objective of this work is to develop a computer software in visual basic programming language to predict theoretical field capacity and effective field capacity of a field operation for implement with different effective widths and different operating speeds.

To meet the overall objective, the following specific objectives will be addressed:

- Determine the important parameters for tillage, planting, fertilizers, weed control and harvesting machines.

- Design a computer program that determines both theoretical field capacity and effective field capacity.

- Compare the obtained data using the proposed program with the actual data as the applied operations.

\section{MATERIALS AND METHODS}

The data used in this study were collected through actual field experiments and survey covering different field crops in El-Kassasin, Belbis, New El-Salhia and West Nubaria on sandy loam soils as shown in table (1). Information from many farms were collected through repeated visits. The data covered information on farm mechanization activities as well as other farm activities included, the predicted implement performance parameters, total field time, theoretical field capacity and effective field capacity.

The studied machines for the different mechanized operations were as follow:

- Soil bed preparation was done by chisel plow, mouldboard plow, disc plow, rotary plow, subsoiler, spike harrow, disk harrow, rollers and cultivators. 
- Planting machines include spreaders, seed drill and planters

- Fertilizers and weed control machines.

- Harvesting machines include self-propelled harvesters and combines.

All above data mentioned machines were studied to calculate and estimate both theoretical and effective field capacities. The data were gathered and analyzed in an Excel spreadsheet for the data analysis for different mechanized operations of different field crops in the four regional areas as shown in Fig (1).

Table (1): The collected data of the studied farms.

\begin{tabular}{||c|c|c|c||}
\hline Region & Crop & $\begin{array}{c}\text { Fields } \\
\text { Size(fed) }\end{array}$ & Soil Texture \\
\hline Kassasin & Corn & 28.2 & \multirow{2}{*}{ Sandy Loam } \\
\hline Belbis & Wheat & 27.9 & \\
\cline { 1 - 3 } New El-Salhia & Corn & 30.5 & \\
\hline West Nubaria & Sugar beet & 37.1 & \\
\hline
\end{tabular}

The important parameters affecting theoretical and effective field capacities of the studied machines were machine width and forward speed.

A computer program was designed to calculate both theoretical and effective field capacities. Data of the studied machines were fed to the program at different working widths and different forward speeds. The variables illustrated in Table (2) were used as inputs for a software developed in visual basic programming language, the program was built to be used simply by smart phones for technicians and agricultural engineers, the basic flow chart of the software was shown in Fig. (2).

Field efficiency was fed also to the program as input based on data taken from ASABE (ASABE 2011) .

Table (2): Programming inputs.

\begin{tabular}{|c|c|}
\hline Variables & Units \\
\hline Operating speed & $\mathrm{Km} / \mathrm{h}$ \\
\hline Implement effective width & $\mathrm{m}$ \\
\hline Productive time & $\mathrm{sec}$ \\
\hline Average time for turn & $\mathrm{sec}$ \\
\hline Time losses & $\mathrm{sec}$ \\
\hline
\end{tabular}


FARM MACHINERY AND POWER

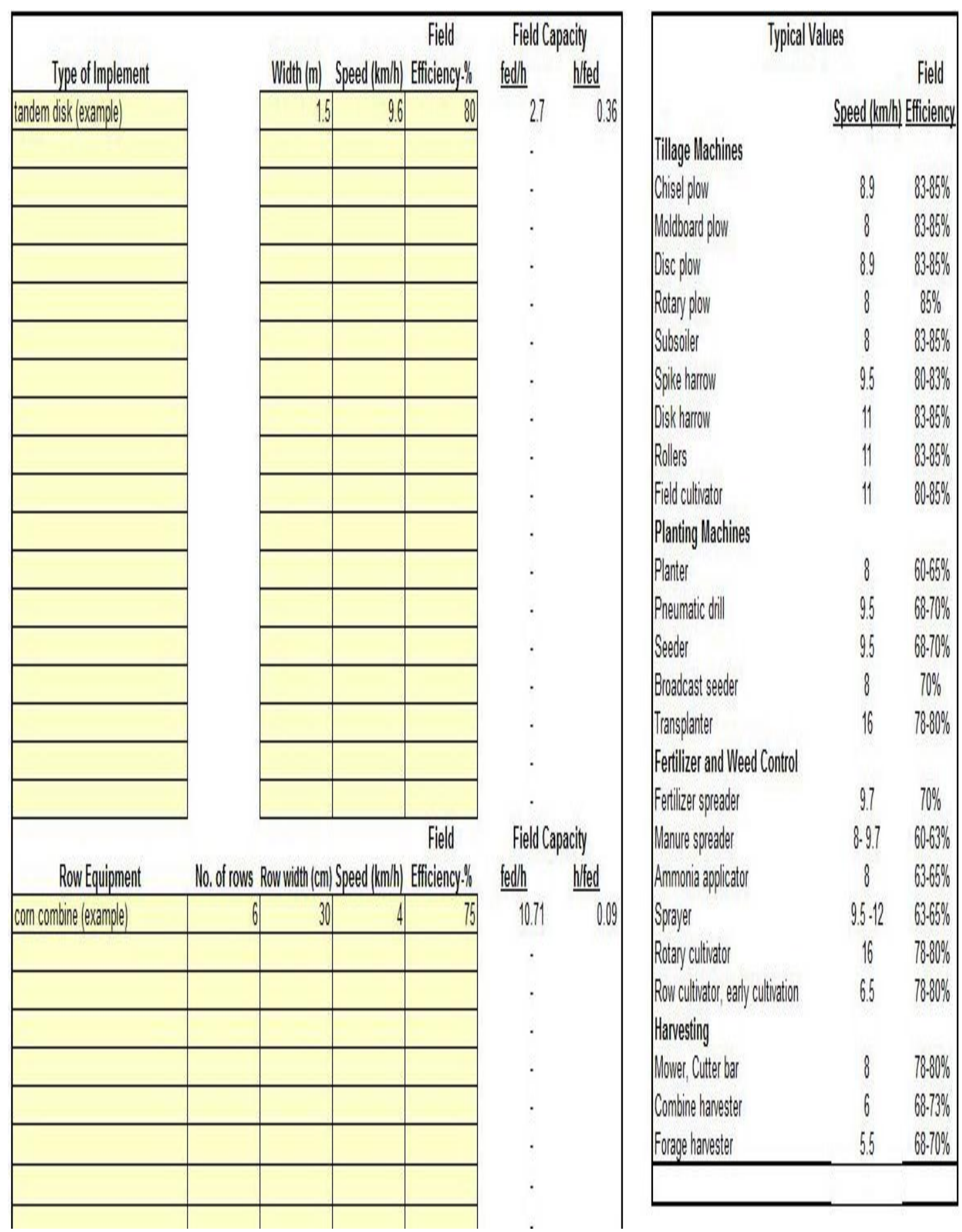

Fig. (1) Data gathered and analyzed in an Excel spreadsheet. 


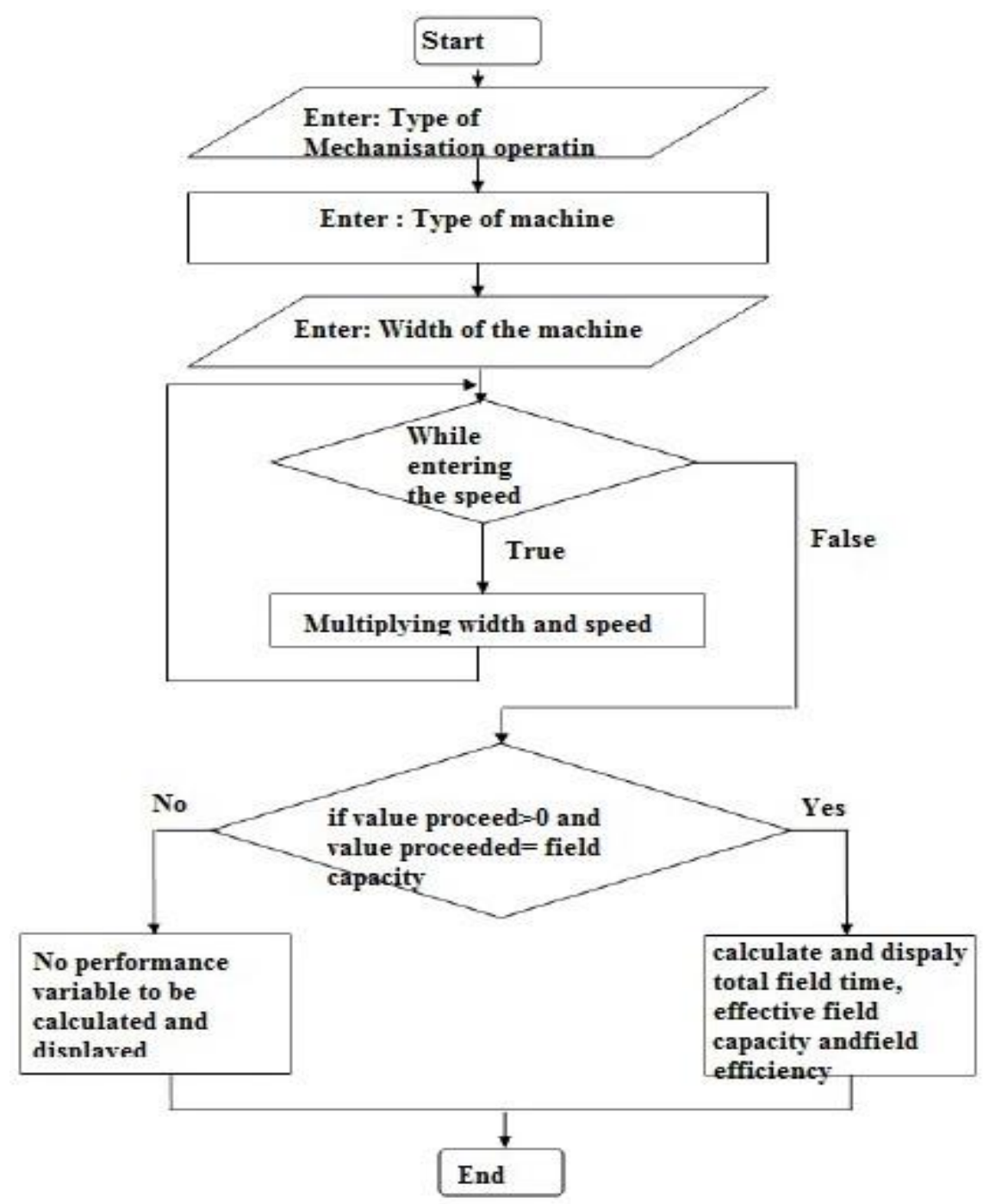

Fig. (2) Basic flow chart of the software.

\section{RESULTS AND DISCUSSION}

Discussion will cover the steps of using the developed program for calculating both theoretical and effective field capacities as follow:

Front view of field capacity software:

The front view of the field capacity software was divided into four different agricultural mechanization operations sections, tillage machines, planting machines, fertilizer and weed control machines and harvesting machines. As shown in fig. (3). 


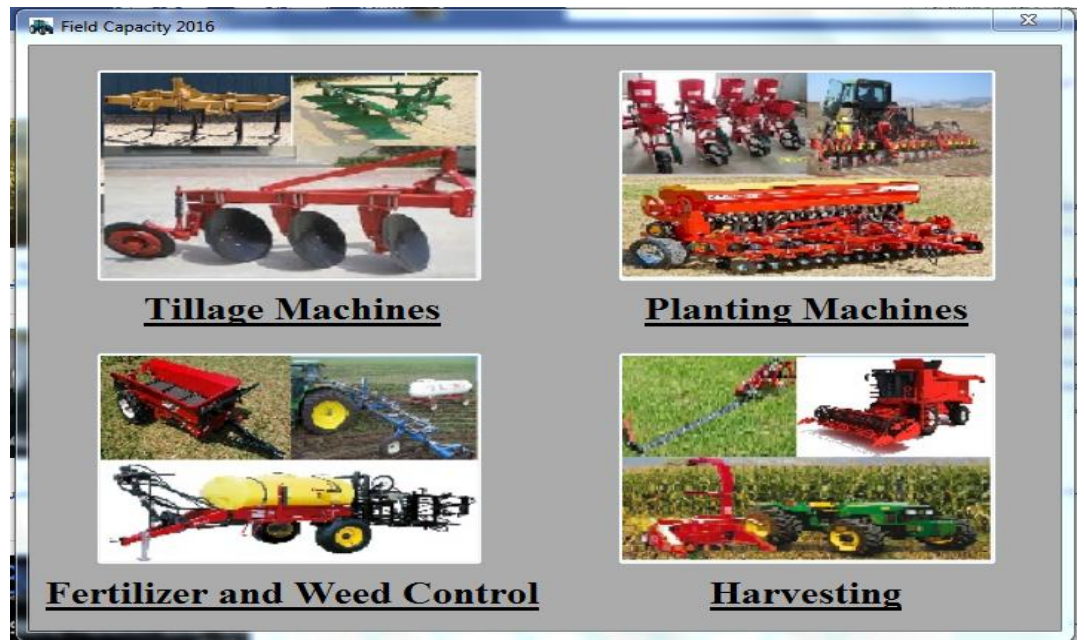

Fig. (3): Front view of the field capacity software.

Selecting the agricultural mechanization operation:

According to the agricultural mechanization operation selected, a page for some selected different machines concerning the mechanization operation were showed as illustrated in fig. (4)

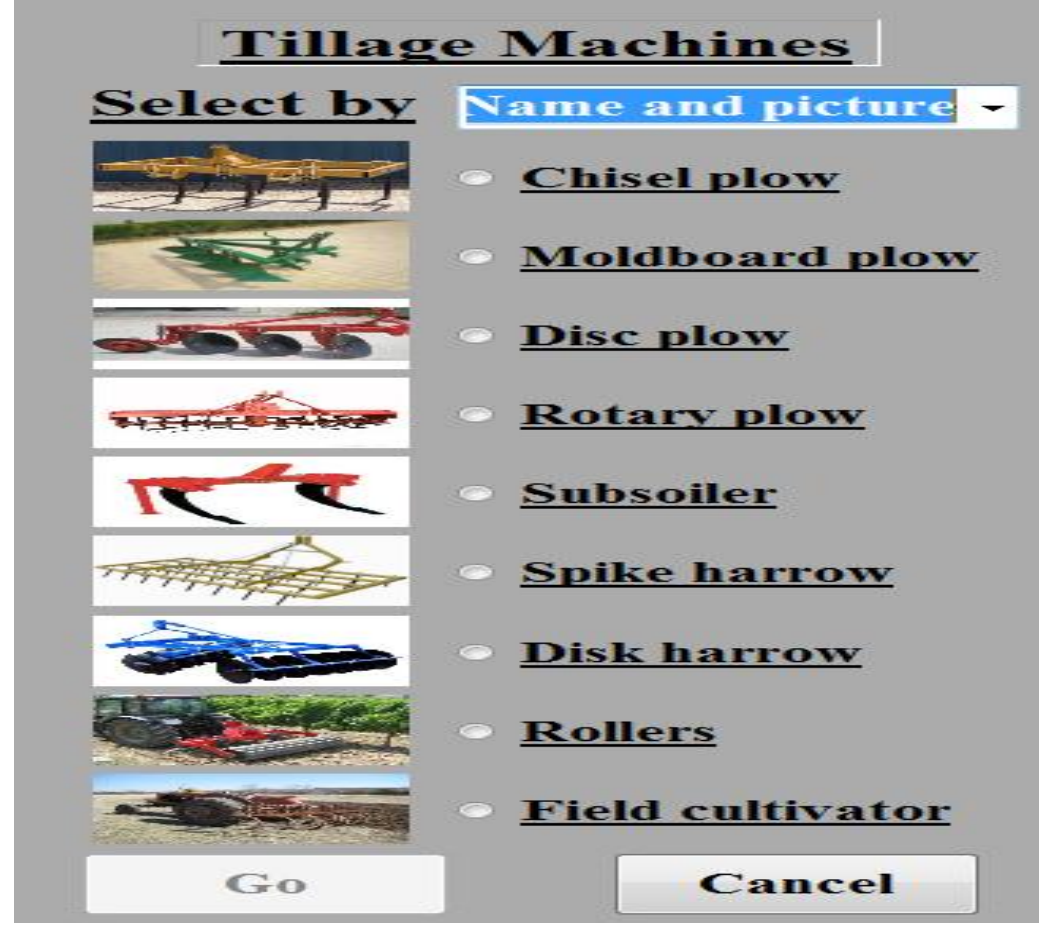

Fig. (4): Selecting the machine. 


\section{Software verification}

The software was verified for the implement width $(\mathrm{m})$, forward speed $(\mathrm{km} / \mathrm{h})$ and field efficiency $(\%)$. It was observed that, as soon as entering input data the unit displays the results. The predicted results were identical to that obtained in the field experiments. This means that, the unit is able to calculate the required parameters correctly. By inserting the choice of the result by ha/h or fed/h, and then inserting the width (m), Forward speed $(\mathrm{km} / \mathrm{h})$ and field efficiency $(\%)$, the calculated performance will be showed as illustrated in fig. (5).

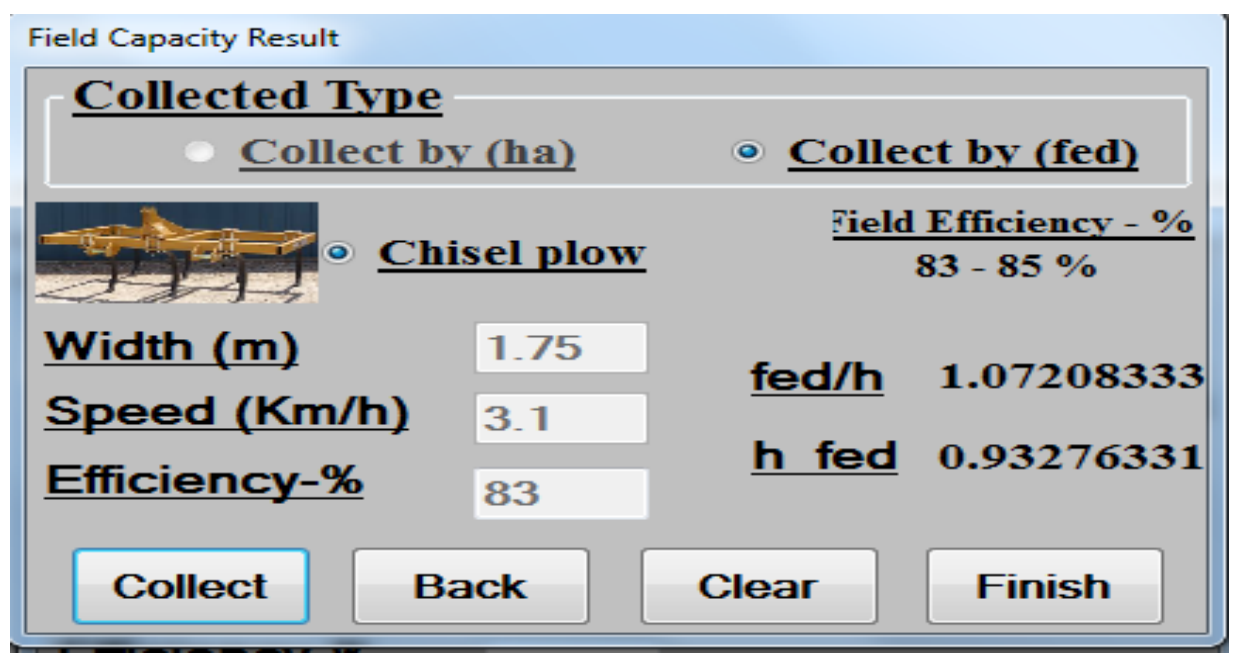

Fig. (5) Calculating the field capacity for the agricultural mechanization operation.

\section{Software validation}

The software validity was tested for five selected implements to compare between actual and predicted effective field capacity (ha/h) as shown in Table (3). The root mean square of the error criterion was used as a comparison measure. The results showed very low RMSE (0.179) between the predicted and actual data for field capacity. Moreover no significant difference (at 5\%) between the system calculations and actual data. These indicate a high consistency between actual data and the system calculations. 
Table (3): Comparison between predicted and actual field capacity (ha/h).

\begin{tabular}{ccccc}
\hline \multirow{2}{*}{ Implement } & $\begin{array}{c}\text { Implement } \\
\text { speed(km/h) }\end{array}$ & $\begin{array}{c}\text { Implement } \\
\text { width(m) }\end{array}$ & \multicolumn{2}{c}{ Field capacity (ha/h) } \\
& 5.1 & 2 & 1.3 & 1.4 \\
\hline Chisel plow & 8.2 & 3.7 & 2.7 & 2.9 \\
Spike harrow & 8.2 & 1.7 & 1.4 & 1.5 \\
Disk harrow & 8.1 & 3.2 & 1.8 & 1.9 \\
planter & 6.6 & 14 & 9.6 & 9.9 \\
combine harvester & \multicolumn{5}{c}{0.179} \\
\hline RMSE & & \multicolumn{5}{l}{} \\
\hline
\end{tabular}

RMSE $=$ Root mean square of the error

The measured field capacities of the machinery involved in the potato production were calculated. The data give the field efficiency and operating speed ranges with typical value for each machinery type. The selected values of field efficiency and calculated field capacity are presented in the Table (4). However, large variations were found in the measured field efficiency and field capacity for the five main operations in the experimental fields. The possible factors that led to the variations include the machine maneuverability, the fieldwork pattern, field shape and size, soil and weather conditions.

Table (4): Comparison between measured data and ASABE normal data.

\begin{tabular}{|c|c|c|c|}
\hline \multirow{2}{*}{$\begin{array}{c}\text { Agricultural } \\
\text { mechanization } \\
\text { operation }\end{array}$} & $\begin{array}{c}\text { Field Efficiency } \\
\text { rang (\%) } \\
\text { (mean) }\end{array}$ & $\begin{array}{c}\text { Field } \\
\text { capacity } \\
(\mathbf{h a} / \mathbf{h}) \\
(\mathbf{m e a n})\end{array}$ & $\begin{array}{c}\text { Forward } \\
\text { speed } \\
(\mathbf{k m} / \mathbf{h}) \\
(\mathbf{m e a n})\end{array}$ \\
\hline Seedbed preparation & $\begin{array}{c}58.36-78.71 \\
(71.33)\end{array}$ & $\begin{array}{c}1.12-1.81 \\
(1.46)\end{array}$ & $\begin{array}{c}4.90-5.15 \\
(5.05)\end{array}$ \\
\hline Seedbed fining & $\begin{array}{c}65.69-73.44 \\
(68.53)\end{array}$ & $\begin{array}{c}0.44-0.62 \\
(0.53)\end{array}$ & $\begin{array}{c}3.42-3.82 \\
(3.58)\end{array}$ \\
\hline Planting & $\begin{array}{c}31.89-48.25 \\
(40.32)\end{array}$ & $\begin{array}{c}0.39-0.56 \\
(0.47)\end{array}$ & $\begin{array}{c}5.04-5.45 \\
(5.25)\end{array}$ \\
\hline Spraying & $\begin{array}{c}53.20-76.79 \\
(69.68)\end{array}$ & $\begin{array}{c}7.53-12.50 \\
(10.21)\end{array}$ & $\begin{array}{c}5.76-6.12 \\
(5.85)\end{array}$ \\
\hline Harvesting & $\begin{array}{c}58.97-72.83 \\
(67.68)\end{array}$ & $\begin{array}{c}0.37-0.62 \\
(0.51)\end{array}$ & $\begin{array}{c}4.51-4.68 \\
(4.6)\end{array}$ \\
\hline
\end{tabular}




\section{CONCLUSION}

A computer software was developed with visual basic programming language to predict the field performance parameters of implement with different width operated at different speeds. The results demonstrated that referenced data gathered during field mechanized operations can be a useful tool to observe machine and operator patterns and thereby be useful for machinery management decisions. Using this data concluded that the field efficiencies were gives the producer the ability to assess the actual capacity reductions due to farming/operator practice, machinery patterns and field operations.

\section{REFERENCES}

Ahmed, M. and Haffar H. (1993). Comparison of five tillage systems for cotton production in Rahad Scheme. A.M.A, 24 (2): 17-20.

ASAE (2003). FEB03 STANDARDS. ASAE EP 496.2. Agricultural Machinery Management. American Society of Agricultural Engineers, 367-372.

ASAE (2011). Agricultural machinery management data D497.7. In ASABE STANDARD 2011. (Ed.), ASABE. St. Joseph, MI, USA: American Society of Agricultural and Biological Engineers.

Belal M. and Dahab M.(1997). Effect of soil condition on a two wheel drive tractor performance, using three types of tillage implements. University of Khartoum, J. Agri. Sci, 5 (2): 1-22.

Bower C. (1985). Southeastern tillage energy data and recommended reporting. Trans. ASAE, 28 (3), 731-737.

Donnell H. (2001). Farm power and machinery management. Wiley, Technology \& Engineering - pp368.

Kepner A., Bainer R. and Barger L.(1978) Principles of farm machinery, $3^{\text {rd }}$ Edition. pp: $23-47$

Morad M. and El-Shazly M. (1994). Effect of some operating parameters on rotary plow performance. Misr J. Agri. Eng., 11 (4): 1009-1020. 
Robert D., Paul J. and Dale R. (2000). Field efficiency determination from spatial data. Paper number 001013. An ASAE meeting presentation.

Renoll E. (1981). Predicting machine field capacity for specific field and operating conditions. Trans. of the ASAE 24(1) 45-47.

Witney B. (1988). Choosing and using farm machines. Edinburgh, Land Technology Ltd, pp: 412.

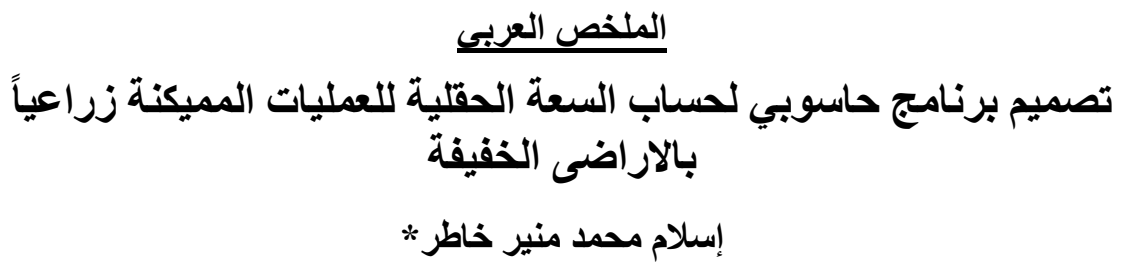

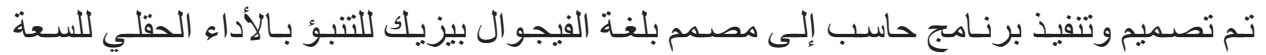

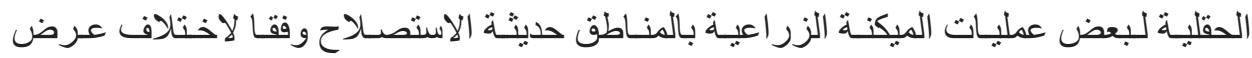

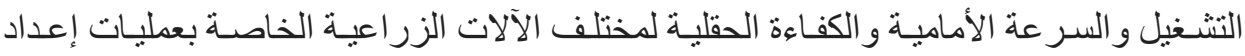

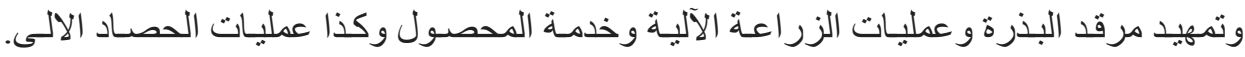

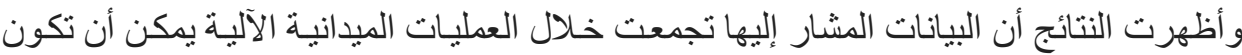

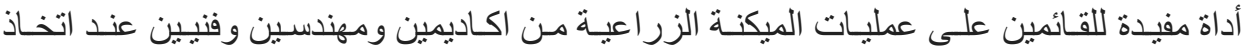

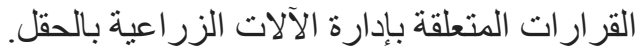

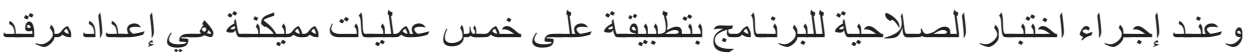

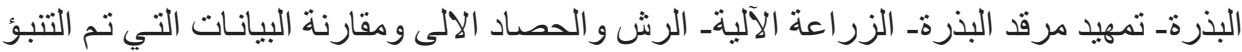

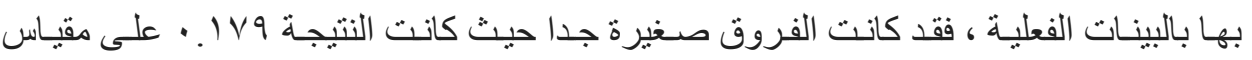

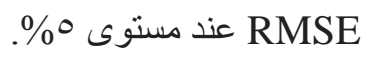

*مركز بحوث الصحراء- القاهرة- مصر. 